\title{
Undergraduate Sport Management Students' Perceptions of Leadership Skills Through Service Learning
}

\author{
Bryan Romsa \\ Assistant Professor \\ South Dakota State University \\ Katelyn Romsa \\ Assistant Professor \\ South Dakota State University \\ Jon Lim \\ Associate Professor \\ Minnesota State University, Mankato \\ Scott Wurdinger \\ Professor \\ Minnesota State University, Mankato
}

\begin{abstract}
Researchers have discovered that service learning affects students' academic, personal, and social development. However, currently there is a gap in literature analyzing ways in which service learning affects students' perceived leadership skills. This study examined the effectiveness of service learning on the perceived leadership skills of 74 sport management undergraduate students at a mid-sized, Midwestern, public university using Kouzes' and Posner's Student Leadership Practices Inventory instrument, which examines leadership practices in five areas: Model the Way, Inspire a Shared Vision, Challenge the Process, Enable Others to Act, and Encourage the Heart. The results of this study may help faculty members and administrators to better understand the potential of utilizing service learning projects in their classrooms as a vehicle for their students to develop quality leadership practices. Recommendations for further research and practice are also discussed.
\end{abstract}

\section{Introduction}

The need for leadership is found in all areas of society. As our world continues to change and becomes increasingly complex, the need for leaders will increase (Kouzes \& Posner, 2007; Maak \& Pless, 2009; Pless, Maak, \& Stahl, 2011). Currently there is a lack of leadership in both the private and public sector (Fernandez \& Rainey, 2006; George, 2007; Hooijberg \& Choi, 2001). One important goal of higher education is to prepare students, the leaders of tomorrow, for the professional world. Yet few formal training opportunities are offered to help them develop skills in personal leadership, 
organizational leadership, or community leadership (Cress, Astin, Zimmerman-Oster, \& Burkhardt, 2001; Ricketts \& Rudd, 2001; Schumacher \& Swan, 1993). Leadership development must become an integral part of college students' education to prepare them for professional careers and career advancement. In order to help college students become leaders as they transition from school to work, faculty members and administrators should consider providing them with opportunities to develop leadership skills.

Possessing leadership skills is vital for sport managers (Pederson, Parks, Quarterman, \& Thibault, 2011). A recent study has shown that business management education programs are not meeting the leadership needs of the industry (Rhee \& Sigler, 2010). This may also be true in sport business, where sport management education programs are not meeting the needs of the sport business industry (Litzky, Godshalk, \& Walton-Bongers, 2010; Rhee \& Sigler, 2010). Service learning projects have been used to help business management students develop and understand their leadership skills (Litzky et al., 2010; Rhee \& Sigler, 2010). The educational practices of service learning used in business management education could also be used in sport management education programs to help students develop their leadership skills. However, more research is needed to determine ways in which service learning can also be used as a tool to help sport management students develop and understand their leadership skills. Some leadership skills that are necessary to be successful in several different types of industries include credibility, shared vision, ability to change, collaboration, and community values (Kouzes \& Posner, 2007; Taylor, Martin, Hutchinson, \& Jinks, 2007).

Students must be given the opportunity to engage in real world activities in order for these types of leadership skills to be developed, which will equip them with the ability to lead successful organizations in the private and/or public sector. One real world activity for developing leadership skills is service learning. Service learning connects theory to reality and provides students the opportunity to learn through action, which helps them to develop greater self-awareness, confidence, and commitment (Eyler, 2002; Rhee \& Sigler, 2010; Snell, Chan, \& Chan, 2015). In particular, service learning provides students with the opportunity to gain hands-on experience outside of the classroom where they are able to work directly with local businesses and non-profit organizations. These experiences allow students to put their leadership skills into practice while working with real world problems.

The sport industry is an example of an industry where leadership is inadequate (Hardy, 1987; The Sport Industry Needs, 2015). The sport industry is one of the largest and fastest growing industries in the United States. The sport industry "includes not only the economy activity of sports teams and recreational sports but also the spending of participants, spectators, and sponsors in connection with sports events" (Meek, 1997, p. 16). According to a recent Plunkett Research study (2010), the sport industry is currently worth $\$ 414$ billion. To put the size of this industry into perspective, the sport industry is twice the size of the United States' auto industry and seven times the size of the movie industry. 
This vast and diverse sport industry is in need of dynamic leaders possessing leadership skills. According to Kouzes and Posner (2007), leaders have the ability to articulate their vision, model their values, motivate and inspire others, think critically to challenge the status quo and make changes, foster collaboration to build trust, and acknowledge accomplishments of high-performance teams. The success or failure of sport organizations is often placed at the feet of the leaders of those organizations. In order for leaders to succeed in sport business it is important for them to enter the industry with a developed set of leadership skills (Soucie, 1994; Taylor et al., 2007).

Presently, there is also a need for exemplary leaders in government, education, and business (Fernandez \& Rainey, 2006; George, 2007; Hooijberg \& Choi, 2001). Skills necessary for leadership include knowing one's values, articulating one's vision and role-modeling one's values, motivating to inspire others, thinking critically to challenge and make changes, and fostering collaboration to build trust and acknowledge accomplishments of high-performance teams (Kouzes \& Posner, 2007; Taylor et al., 2007). All of these skills may be developed through service learning opportunities.

\section{Purpose of the Study}

Many scholars have analyzed the effects service learning has had on student achievement, intellectual development, and career and social development (Billig, 2007; Carver, 1997; Daynes \& Longo, 2004; Eyler \& Giles, 1999; Jackowski \& Gullion, 1998; Wilczenski \& Coomey, 2007). Service learning has been applied in the area of sport management education to effectively develop student leadership skills (Rhee \& Sigler, 2010); however, few scholars have analyzed the effects service learning has on students' perceived leadership skills (Rozeboom, 2008). Given the gap in the literature, the purpose of this study was to examine the extent to which a service learning activity had on the perceived leadership skills of undergraduate sport management students at a midsized, Midwestern, public university using Kouzes' and Posner's Student Leadership Practices Inventory (StudentLPI) instrument, which examines leadership practices in five areas: Model the Way, Inspire a Shared Vision, Challenge the Process, Enable Others to Act, and Encourage the Heart.

\section{Review of Literature}

Survey results from the Association of American Colleges and Universities' National Leadership Council for Liberal Education and America's Promise (LEAP) indicate that of 305 employers interviewed, $63 \%$ believe that college graduates lack the leadership skills needed for a global economy and for promotion (Kuh, 2008). The lack of leadership skills America is facing as a society may also be found in the sport business industry. Service learning may provide sport management students the opportunity to develop leadership skills, as it has in business management students (Litzky et al., 2010; Rhee \& Sigler, 2010). This review of literature includes two streams of literature: (a) the historical overview of service learning and (b) service learning empirical studies. 
Historical Overview of Service Learning. Service learning can be traced back to John Dewey's theory of experiential learning. In order for learners to be prepared for the present and future there was a need for them to do more than study facts in a classroom. They needed to get out of the classroom and take control of their own learning in real world experiences (Dewey, 1938). During the 1930s service learning opportunities grew under President Franklin D. Roosevelt. The creation of the Civilian Conservation Corps allowed young people the opportunity to serve their communities for six to 18 month terms (Titlebaum, Williamson, Daprano, Baer, \& Brahler, 2004). During the 1950s the Truman Commission stated that the purpose of higher education was to serve the public (Hinck \& Brandell, 2000). President John F. Kennedy provided students with further service opportunities with the creation of the Peace Corps and Volunteers in Service to America.

Service learning began gaining traction in the mid-1960s. Bill Ramsey and Bob Sigmon first used the term "service learning" in 1965 when college students from eastern Tennessee began working on tributary development for the Tennessee Valley Authority (Titlebaum et al., 2004). Service learning was later defined in 1969 at the Atlanta Service Learning Conference as "the integration of the accomplishment of the tasks that meet human needs with conscious educational growth" (Titlebaum et al., 2004). The following decade, the National Center for Service Learning published the "Three Principles of Service Learning" in Synergist, a journal promoting the link between service and learning (Titlebaum et al., 2004). Through the 1980s various service learning organizations were developed including The National Youth Leadership Council, which allowed students to participate in learning experiences while improving their communities (Titlebaum et al., 2004). Finally, the Wingspread Conference and the Minnesota Legislature began funding grants for post-secondary service learning in 1989 (Titlebaum et al., 2004). The National and Community Service Act was passed in 1990, which provided funding to colleges and universities, nonprofit organizations, and other schools, to promote and support service learning activities and established Learn and Serve America, a national service program active from 1994-2011, which engaged students, educators, youth workers, and community members in service learning opportunities. The program made grants to schools, higher education institutions, Native American tribes, and community-based organizations to assist in the planning and implementation of service learning programs. (Titlebaum et al., 2004). Today, academic institutions are continuing to react to internal and external forces that are expecting student learning outcomes of civic engagement and leadership and are utilizing assessment measures to evaluate these outcomes (Ostrander, 2004). Service learning can provide an opportunity for institutions to meet the expectations of civic engagement and leadership.

Empirical Studies of Service Learning. Service learning allows students to develop leadership skills through real world experiences, as they apply what they are learning about in the classroom to reality (Eyler, 2002). As a result of service learning experiences, students leave the classroom and enter the world better equipped to engage in the global economy that awaits them (Billig, 2007). Service learning also allows students opportunities to connect with their community, which increases their learning, self-confidence, and compassion for others (Eyler, 2002). In short, when students engage 
in service learning they improve their leadership skills, which assists them as they transition to work in the private and/or public sector.

There are many researchers who have studied how service learning can be used as a vehicle to help individuals develop leadership characteristics. Giles and Eyler (1994) examined changes in social and personal responsibility resulting from a service learning experience. The participants included 72 students at Vanderbilt University who spent the first five weeks talking with representatives from social service agencies and the final eight weeks volunteering three hours a week at these agencies. The Vanderbilt Survey consisted of open-ended questions related to conceptions of issues that clients faced, and about their own learning expectations and perceptions. The results from the survey indicated that students experienced significant increases in their beliefs that people can make a difference, and that they should be involved in community service, particularly in leadership and politics.

Blackwell (1996) explored how service learning impacts the perceptions of students' leadership abilities. A survey of 142 undergraduate students compared their perceptions based on demographic information such as their age, gender, classification, school affiliation, and outside employment. The results from the study indicated that students strongly supported the notion of service learning in college, $85 \%$ believed service learning should be incorporated into more classes, and 93\% indicated that service learning helped them grow intellectually and emotionally.

Eyler, Giles, and Schmiede (1996) applied Kolb's (1984) experiential learning theory and his Learning Style Inventory utilized as a tool used to understand and explain learning behaviors that occur from service learning opportunities. The study provided an extensive amount of information about the importance of self-reflection. Eyler et al. (1996) described reflection as "a process specifically structured to help examine the frameworks that we use to interpret experience; critical reflection pushes us to step outside the old and familiar and to reframe our questions and our conclusions in innovative and more effective terms" (p. 13). They contended that reflection was a critical component to learning.

Furco (2002) investigated 529 high school students who participated in a community service experience. The quasi-experimental study measured students' development across six educational domains: academic, career, personal, social, civic, and ethical using a pre/posttest survey data. The findings indicated that the students who engaged in service over the course of the year showed significantly higher gains in developing more positive attitudes toward school, themselves, others, the future and their community. Students in the service group were more positive, more self-confident, and more philosophical than those not in the service group.

Astin and Sax (1998) conducted a national study to determine if service learning increased the knowledge and life skills of students participating in community service learning experiences. Forty-two college institutions sponsored by Learn and Serve America of Higher Education were surveyed. The sample consisted of 3,450 students 
who were engaged in service learning activities. The study design was comprised of a pre-and post-experience survey and a quasi-experimental survey with 35 student outcome measures. The purpose of the study was to determine the increase of knowledge and life skills measured by student self-report elements such as critical thinking, interpersonal skills, leadership skills, social self-confidence, knowledge of different races and cultures, and conflict resolution skills. The students participated in the following activities: tutoring, improving neighborhood environments and community health, preventing crime, and working with the homeless, the poor, and the elderly. The data sources were the self-reported survey and institutional records: Cooperative Institutional Research Program Freshman Survey, Scholastic Aptitude Test, American College Testing scores, enrollment data, and 35 student outcomes were measured in 5 student cohorts from 19901994. The findings determined that the more time students devoted to service, the more positive the effect it had on them. The researchers found that leadership ability was significantly enhanced by participating in service learning activities.

In an international study conducted in Hong Kong, researchers explored how service learning could be used as a vehicle to help undergraduate students develop leadership skills (Snell, Chan, Ma, \& Chan, 2015). The participants included 49 undergraduate students who participated in a course-embedded service-learning team project. As a result of the project, students became more aware of serviceleadership behaviors and more confident in those behaviors. Students also attained new leadership competencies such as commitment, developing relationships, and initiative-taking.

Wurr and Hamilton (2012) similarly investigated how service learning assisted the development of student leadership. The eight participants included 6 students, 1 alumna, and 1 faculty who were interviewed about their growth as leaders. They found that service learning could provide an opportunity to formulate a leadership identity, meaning that those involved in service-learning programs can advance from seeing leadership exclusively for those who are in positional leadership roles (stage 3), to understanding that leadership can come from anyone within a group (stage 4), to accepting responsibility for supporting others and internalizing themselves as leaders (stage 6).

In another study, researchers examined college students during their senior year to address multiple examples of student learning in service learning activities and its relationship to leadership development (Gardner, Van der Veer \& Associates, 1998). The researchers provided examples of leadership programs and majors at various colleges and universities and the way in which service learning was incorporated and made recommendations for enhancing students' senior-year experience. Some of the recommendations for service learning programs they suggested were for students to "fulfill public service obligation, earn money, build a resume, and learn under supervision a range of skills and understandings that will serve them through their life" (p. 278).

The goals of service-learning research have been set too low and there has not been enough attention given to defining and measuring appropriate outcomes (Eyler, 
2002). Thus, the recommendations of Gardner et al. (1998) have provided researchers and practitioners with a starting point from which they can further examine service learning and student learning. Service learning has the potential to develop the "personal and social development, civic engagement, academic achievement, and career awareness" of those who are involved in the learning (Billig, 2002, p.185). Litzky et al. (2010) have developed a "how to" guide for teaching a service learning course in social entrepreneurship and community leadership. The service learning activities in the course are generalizable to several management education contexts that seek to enhance learning and leadership by creating partnerships between the university, its students, and its community.

Additional scholars have examined how service learning can help business management students develop and understand their leadership skills (Litzky et al., 2010; Rhee \& Sigler, 2010). Litzky et. al (2010) found that business management graduate students were able to develop their leadership skills through serving learning by mentoring high school students with business and strategic planning. Although the educational practices of service learning used in business management can aid in understanding the development of leadership skills in sport management, a limitation of these studies is that they are not based in a leadership theoretical framework (Dugan, 2006). Currently, there is not any published research investigating the effectiveness service learning has on student leadership skills in the field of sport management. To address this gap in the literature and increase the knowledge in this area, we conducted a study examining the effectiveness of service learning on the perceived leadership skills of sport management undergraduate students.

\section{Research Questions}

The purpose of this study was to examine the effectiveness of service learning on the perceived leadership skills of sport management undergraduate students at a midsized, Midwestern, public university using Kouzes' and Posner's Student Leadership Practices Inventory (StudentLPI) instrument. To this end, the following research questions guided this study:

1. How does a service learning experience affect the self-reported perceptions of leadership skills in sport management undergraduate students?

2. How does the lack of a service learning experience affect the self-reported perceptions of leadership skills in sport management undergraduate students?

\section{Methods}

Research Design. A quasi-experimental research design using a pre- and post-test format of the Student LPI Self survey was used to examine the effectiveness service learning had on the perceived leadership skills of sport management undergraduate students. This research design was chosen because the experimental group and the control group were selected without random assignment (Creswell, 2009). Only the experimental group participated in a service learning experience. Undergraduate students enrolled in 
four different sport management courses were assessed in an attempt to measure the effect service learning had on their perceived leadership skills. Two of the courses had college students participate in service learning (experimental group), and two of the courses did not (control group).

Students in the experimental group were given a pre-test of the Student LPI Self to acquire a baseline of perceived leadership skills. The students then began planning, organizing, and designing a service learning project in consultation with their professor that took place with an outside organization. Students then executed their service learning project and spent approximately 70 hours both inside and outside the classroom working on their project. This amount of time was necessary because research has shown that service learning projects need to occur over a significant amount of time, at least a semester in length, in order for the activity to have an impact on the students (Spring, Dietz, \& Grimm, 2006). This amount of time allowed students to prepare, execute, reflect, and demonstrate results. At the end of the semester the students were given the Student LPI Self to measure the change in perceived leadership skills.

Students in the control group were also first given a pre-test using the Student LPI Self to acquire a baseline of perceived leadership skills. Next the students were involved in a traditional lecture based course where there was no service learning experience. At the end of the semester the students were given the Student LPI Self to measure the change in perceived leadership skills in the students after a semester in a traditional lecture based course.

Participants. The participants of this study included 74 sport management undergraduate students registered in one of four courses, Event Management in Sport, Sport Ethics and Professional Development, Foundations of Sport Management, and Legal Aspects of Physical Education and Sport at a mid-sized Midwestern public university. The Event Management in Sport and the Sport Ethics and Professional Development courses were the experimental group and participated in a service learning activity. The Foundations of Sport Management and Legal Aspects of Physical Education courses were the control group and did not participate in a service learning activity. Each of these courses had an enrollment of 20-25 students majoring in sport management, all students were over 18 years of age, and the courses consisted of $86.5 \%$ male students and $13.5 \%$ female. Over the course of one semester, this study involved 74 undergraduate students with 47 sport management students participating in a service learning activity. A majority $(62.5 \%, \mathrm{n}=45)$ of the participants were 21 or 22 years old; $23.6 \%(n=17)$ were 19 or 20 ; and $13.9 \%(n=10)$ were between the ages of 23 and 32 . Also, the majority of the participants were juniors $(45.9 \%, \mathrm{n}=34)$ and seniors $(43.4 \%$, $\mathrm{n}=32)$; and $10.8 \%(\mathrm{n}=8)$ were sophomores. Finally, the vast majority $(90.4 \%, \mathrm{n}=66)$ of the participants were white; $8.2 \%$ were 6 African American $(n=6)$; and 1.4\% was Asian $(\mathrm{n}=1)$.

Instrumentation. The data for this study was collected using the Student Leadership Practices Inventory (Student LPI) Self version (Kouzes \& Posner, 2006), a Likert scale survey. The original Leadership Practices Inventory (LPI) was developed by using "case 
studies from over 2,500 managers about their personal-best experiences as leaders" (p. 6). The Student LPI consists of 30 descriptive statements paralleling those found in the original LPI. The Student LPI was chosen for this study because of its reliability and validity that has been established over time. Kouzes and Pozner's (2012) studies indicate adequate internal reliability (Cronbach alpha) for the five subscales as follows: .77 for modeling the way, .87 for inspire shared vision, .80 for challenge the process, .75 for enable others to act, and .87 for engage the heart. Fields and Herold (1997) used Kouzes and Posner's Student LPI to measure transformational and transactional leadership in an engineering firm. These researchers reported a "reliability of the scores on the five LPI scales in the sample of 1,892 , ranging from .82 to .92 , which is similar to reliability scores reported by Kouzes and Posner" (p. 575).

The Student LPI consists of 30 reflective questions categorizing the participants' leadership skills into five dimensions: Modeling the Way, Inspiring a Shared Vision, Challenging the Process, Enabling Others to Act, and Encouraging the Heart. Modeling the Way is accomplished by leaders staying true to their personal values and modeling their values within the organization. Inspiring a Shared Vision occurs when leaders are able to lead the organization in a way that creates enthusiasm and excitement for their shared vision. Challenging the Process involves leaders encouraging members of their organization to challenge the status quo and to look for ways to improve the organization. Enabling Others to Act promotes cooperative goals and trust by empowering others to share their ideas. Encouraging the Heart allows leaders to show appreciation for the accomplishments of excellence of those within their organization. Each leadership response was chosen by students on a 1-5 Likert scale: (1) Never, (2) Rarely, (3) Sometimes, (4) Often, and (5) Very Frequently. The Student LPI asks the subjects questions regarding their interaction with those that they are working with. The questions inquire the subjects about their positive work interactions, group communication, and the treatment of others.

Data Collection. Institutional Review Board approval was obtained before the data was collected. The students took the Student LPI Self as a pre- and post-test at the beginning and end of the semester. The service learning project began after the Student LPI Self pre-test was taken and the post-test occurred after the students' service learning projects were completed. Students were informed of the study in the classroom and when the survey was emailed to them with a link to the survey via Survey Monkey. The email explained the purpose of the study and assured respondents that they would remain anonymous and that the results would be kept confidential. Ensuring students anonymity on the survey was particularly important for this study to encourage more truthful responses (Chaudhuri \& Mukherjee, 1988). The students were advised that their completion of the survey was their consent. The Student LPI was given to the students anonymously to protect the privacy of subjects and to maintain confidentiality of data.

Statistical Analysis. Descriptive statistics (percentages, frequency distributions, and ranges) were utilized to describe the demographic characteristics of the participants. Means were utilized to compare the two groups. A paired T test was not used to measure 
a statistical change from the pre-test to post-test for this study because participants' responses were anonymous to encourage more truthful response.

\section{Results}

The first research question analyzed how a service learning experience affects the self-reported perceptions of leadership skills in sport management undergraduate students. The Student LPI Self was administered as a pre-test at the beginning of the semester and a post-test at the end of that same semester. The five leadership practices are identified as Model the Way, Inspire a Shared Vision, Challenge the Process, Enable Others to Act, and Encourage the Heart. Six items in the Student LPI measure each of the five practices. The findings indicated that the students who participated in a service learning activity (experiential group) self-reported a decrease in all five leadership practices. As shown in Table 1, the mean for all five leadership practices decreased. The smallest change was Encourage the Heart, findings revealed means that decreased $(M=24.48, M=24.13)$, followed by Inspire a Shared Vision $(M=23.67, M=23.36)$, Challenge the Process $(M=23.46, M=23.16)$, Enable Others to Act $(M=24.87$, $M=24.36)$, and the biggest means decrease being Model the Way $(M=24.41, M=23.36)$. Enable Others to Act received the highest pretest mean score $(M=24.87)$ followed by Model the Way $(M=24.41)$, Encourage the Heart $(M=24.48)$, Inspire a Shared Vision $(M=23.67)$, and the lowest score being Challenge the Process $(M=23.46)$. Additionally, Enable Others to Act received the highest post-test mean score $(M=24.36)$, followed by Encourage the Heart $(M=24.13)$, Model the Way $(M=23.36)$, Inspire a Shared Vision $(M=23.36)$, and finally the lowest mean score being Challenge the Process $(M=23.16)$.

Table 1.

Leadership Practices and Service Learning Group

\begin{tabular}{lccc}
\hline Leadership Practices & $\begin{array}{c}\text { Pre-test } \\
\text { Mean }\end{array}$ & $\begin{array}{c}\text { Post-test } \\
\text { Mean }\end{array}$ & Change \\
\hline Model the Way & 24.41 & 24.36 & -.05 \\
Inspire a Shared Vision & 23.67 & 23.36 & -.31 \\
Challenge the Process & 23.46 & 23.16 & -.30 \\
Enable Others to Act & 24.87 & 24.36 & -.51 \\
Encourage the Heart & 24.48 & 24.13 & -.35 \\
\hline
\end{tabular}

The second research question asked how not having a service learning experience affects the self-reported perceptions of leadership skills in sport management undergraduate students. Data analysis for this question involved the identification of descriptive statistics that were exhibited for each leadership practice. The findings indicated that the students who did not participate in a service learning activity (control group) self-reported an increase in four of the leadership practices, and a decrease in one. As shown in Table 2, the mean gains for four of the five leadership practices increased and one decreased. The largest increase was Inspire a Shared Vision, $(M=21.83$, $M=22.85)$, followed by Model the Way $(M=22.63, M=23.59)$, Encourage the Heart 
$(M=23.25, M=24.07)$, and Challenge the Process $(M=21.96, M=22.56)$. The only leadership practice that had a mean decrease was Enable Others to Act, $(M=24.46$, $M=23.93)$. Enable Others to Act received the highest pre-test mean score $(M=24.46)$ followed by Encourage the Heart $(M=23.25)$, Model the Way $(M=22.63)$, Challenge the Process $(M=21.96)$, and the lowest score being Inspire a Shared Vision $(M=21.83)$. Additionally, the table shows Encourage the Heart received the highest post-test mean score $(M=24.07)$, followed by Enable Others to Act $(M=23.93)$, Model the Way $(M=23.59)$, Inspire a Shared Vision $(M=22.85)$, and finally the lowest mean score being Challenge the Process $(M=22.56)$.

Table 2.

Leadership Practices and Control Group

\begin{tabular}{lccc}
\hline Leadership Practices & $\begin{array}{c}\text { Pre-test } \\
\text { Mean }\end{array}$ & $\begin{array}{c}\text { Post-test } \\
\text { Mean }\end{array}$ & Change \\
\hline Model the Way & 22.63 & 23.59 & .96 \\
Inspire a Shared Vision & 21.83 & 22.85 & 1.02 \\
Challenge the Process & 21.96 & 22.56 & .60 \\
Enable Others to Act & 24.46 & 23.93 & -.53 \\
Encourage the Heart & 23.25 & 24.07 & .82 \\
\hline
\end{tabular}

\section{Discussion}

Limited scholars have shown that service learning can improve students' selfperceived leadership skills (Rozeboom, 2008). An unanticipated finding of the study was the students who participated in a service learning activity (experiential group) selfreported a decrease in all five leadership practices. This finding does not align with some of the service learning literature regarding service learning and leadership development. Service learning was used to help business management students develop and understand their leadership skills (Litzky et al., 2010; Rhee \& Sigler, 2010).

The literature was used as a tool to develop alternative explanations. A study by Grandzol, Perlis, and Draina, (2010) measuring student leadership skills as a pre-test and post-test looked at team captains versus team members. The researchers found that team captains increased in all five practice inventories whereas team members stayed virtually the same. Since the students in the service learning class in the current study were not given leadership roles or titles they may not have seen themselves taking on leadership roles during the service learning activity.

Another difference between Rhee and Sigler (2010) research and this study is that in an executive education program or an MBA program (Kass \& Grandzol 2011), leadership was discussed into the course and integrated into the service learning activity. The participants in the current study did not have specific leadership tasks, discussion, or language integrated into the classroom. In the future it may be necessary to implement a leadership component to complement the service learning project. 
At many colleges and universities, the lecture format seems to be the centerpiece of instruction where students passively absorb information and regurgitate it in response to periodic exams (McCarthy \& Anderson, 2000). In contrast, students in a service learning course may not have had any prior exposure to service learning and group work and as a result could be uncomfortable doing a service learning experience because of the amount of time they have spent in lecture format classrooms (Jones, Gilbride-Brown, \& Gasiorski, 2005). In addition, students in a service learning course may be unhappy with service learning projects initially because of the amount of work, responsibility, and accountability that is involved in the process. For instance, students in the current study spent approximately 70 hours both inside and outside the classroom working on their service learning project. Thus, their overall attitude toward the experience could be negative where they view service learning as something they are required to do versus something they signed up for (Jones, et al., 2005). This same resistance may have been the case in this study, which could have resulted in their misunderstanding to realize its potential as a vehicle for leadership development.

Finally, students might have begun to better understand their leadership skills after doing the service learning experience. In other words, the students might have over rated their leadership skills on the pre-test due to a lack of leadership experiences. For example, one item in the Student LPI that students rated themselves on was "I praise people for a job well done." At the beginning of the semester before they had been in a situation where they could exhibit that behavior they may have thought that they often praise people for a job well done. During the service learning experience, students interacted with their peers and were put in situations where they had to use their leadership abilities. The students took the post-test after the students had just been through a service learning activity. While taking the post-test, the students might have realized that their leadership skills were not as high as they originally thought they were at the beginning of the semester. Thus, as they took the post-test they may have rated their leadership skills more realistically after having just completed their service learning project.

The second research question asked how not having a service learning experience affects the self-reported perceptions of leadership skills in sport management undergraduate students. The findings indicated that the students who did not participate in a service learning activity (control group) self-reported an increase in four of the leadership practices, and a decrease in one. Although this current finding was unanticipated the literature was used again as a tool to develop alternative explanations. Grandzol, Perlis, and Draina (2010) similarly found that team members who were not identified as captains had essentially no change in their perceived leadership behaviors. Additionally, Kass and Grandzol (2011) examined the leadership development of MBA students enrolled in an Organizational Behavior course. The researchers used a quasiexperimental design for the study. One of the courses was taught in a classroom, and the other course included an outdoor training program called Leadership on the Edge. Kouzes and Posner's LPI was administered to both classes as a pre and post-test. The results of the study found that the students who participated in the Leadership on the 
Edge training program improved their leadership practices in all five areas, and the classroom students did not have a significant change in all five areas.

\section{Recommendations for Further Research \& Practice}

There is a need for exemplary leaders in government, education, and business (Fernandez \& Rainey, 2006; George, 2007; Hooijberg \& Choi, 2001). Skills necessary for leadership include knowing one's values, articulating one's vision and role-modeling one's values, motivating to inspire others, thinking critically to challenge and make changes, and fostering collaboration to build trust and acknowledge accomplishments of high-performance teams (Kouzes \& Posner, 2007; Taylor et al., 2007). The vast and diverse sport industry is also in need of dynamic leaders possessing leadership skills because the success or failure of sport organizations is often placed at their feet.

This study contributes to the growing body of literature by providing information about the impact a service learning activity had on the perceived leadership skills of sport management undergraduate students at a comprehensive public university located in the Midwest. In order for leaders to succeed in sport business it is important for them to enter the industry with a developed set of leadership skills (Soucie, 1994; Taylor et al., 2007). Higher education leaders and faculty can help students acquire these skills through service learning opportunities.

Although the findings of this study suggested that a service learning project did not improve students perceived leadership skills, we recommend several ideas for further research and practice. First, future educators conducting a service learning activity may consider supplementing it with formal leadership training, which could include strategically allocating student responsibilities/leadership positions where they feel as though they are leaders. Scholars have found that it is important for students to first view themselves as leaders in order for them to develop as leaders (Grandzol et al., 2010). For instance, students could be given the leadership responsibility of being a team captain. Team captains are in a leadership role and therefore perceive themselves as a leader versus a team member. Second, future studies may also consider the importance of giving each student in the service learning group a specific leadership role/position within the team project, which may also help them to perceive themselves as a leader. Finally, educators should add and emphasize a reflective component to the study both during and concluding the service learning experience as a tool to help students to better understand, comprehend, and synthesize the transformational learning that occurs through service learning (Eyler et al., 1996). A critical reflection of the learning that occurred through a service learning project may help students to become more self-aware of their leadership skills and reflective of creating goals for self-improvement.

The results of this study may help higher education leaders and faculty to better understand the potential of utilizing service learning projects in their classrooms as a vehicle for their students to develop leadership skills. In addition, the results of this study may assist college students in seeing the value of developing leadership skills through service learning. Finally, it may provide the sport industry with potential employees that 
have developed their leadership skills while participating in an undergraduate education that includes service learning.

\section{References}

Astin, A.W., \& Sax, L. J. (1998). How undergraduates are affected by service participation. Journal of College Student Development, 39(3), 251-263.

Billig, S. H. (2007). Unpacking what works in service-learning: Promising researchbased practices to improve student outcomes. St. Paul, MN: National Youth Leadership Council.

Billing, S.H. (2002). Evaluation of the school district of Philadelphia freedom schools junior leader project. Denver, CO: RMC Research Corporation.

Black, T. R. (1999). Doing quantitative research in the social sciences: an integrated approach to research design, measurement and statistics. London: SAGE.

Blackwell, A. P. (1996). Students' perceptions of service-learning participation in the College of Health and Human Sciences at the University of Southern Mississippi. Unpublished doctoral dissertation, University of Mississippi, Oxford, MS.

Bringle, R. G., \& Hatcher, J. A. (1996). Implementing service learning in higher education. The Journal of Higher Education, 67(2), 221-239.

Carver, R. L. (1997). Theoretical underpinnings of service learning. Theory into Practice, 36(3), 143-149.

Chaudhuri, A., \& Mukherjee, R. (1988). Randomized response: Theory and techniques. New York: Marcel Dekker.

Cress, C. M., Astin, H. S., Zimmerman-Oster, K., \& Burkhardt, J. C. (2001). Developmental outcomes of college students' involvement in leadership activities. Journal of College Student Development, 42(1), 15-27.

Creswell, J. W. (2009). Research design: Qualitative, quantitative, and mixed methods approaches. Los Angeles, CA: Sage.

Cuneen, J., \& Sidwell, M. J. (1998). Evaluating and selecting sport management undergraduate programs. Journal of College Admissions, 158, 6-13.

Daynes, G., \& Longo, N. V. (2004). Jane Addams and the origins of service-learning practice in the United States. Michigan Journal of Community Service Learning, 11(1), 5-13. 
Dewey, J. (1938). Experience and education. New York, NY: Macmillan.

Dugan, J. P. (2006). Explorations using the social change model: leadership development among college men and women. Journal of College Student Development, 47, 217-225.

Eitzen, D. S. (2009). Sport in contemporary society ( $8^{\text {th }}$ ed.). Boulder, CO: Paradigm Publishers.

Eyler, J. (2002). Stretching to meet the challenge: Improving the quality of research to improve the quality of service-learning. In S. H. Billig \& A. Furco (Eds.), Service-learning: Through a multidisciplinary lens (pp. 3-13). Greenwich, CT: Information Age.

Eyler, J., \& Giles, D. E., Jr. (1999). Where's the learning in service-learning? San Francisco: Jossey-Bass.

Eyler, J., Giles, D., \& Schmiede, A. (1996). A practitioner's guide to reflection in service- learning: Student voices and reflections. Nashville, TN: Vanderbilt University Press.

Fernandez, S. and Rainey, H. G. (2006), Managing successful organizational change in the public sector. Public Administration Review, 66(2), 168-176.

Fields, D.L. \& Herold, D.M. (1997). Using the Leadership Practices Inventory to measure transformational and transactional leadership. Educational and Psychological Measurement, 57, 569-580.

Furco, A. (2002). Is service-learning really better than community service? A study of high school service program outcomes. In A. Furco \& S. H. Billig (Eds.), Advances in service-learning research: Vol.1. Service-learning: The essence of the pedagogy (pp. 23-50). Greenwich, CT: Information Age.

Furco, A. (2001). Advancing service-learning at research institutions. New Directions for Higher Education: Developing and Implementing Service-Learning Programs, 114, 67-78.

Gardner, J. N., Van der Veer, \& Associates. (1998). The senior year experience: Facilitating integration, reflection, closure, and transition. San Francisco, CA: Jossey Bass.

George, B. (2007). True north: Discover your authentic leadership. San Francisco, CA: Jossey-Bass/John Wiley \& Sons.

Giles, Jr., D. E., \& Eyler, J. (1994). The impact of a college community service 
laboratory on students' personal, social, and cognitive outcomes. Journal of Adolescence, 17, 327-339.

Grandzol, C. \& Perlis, S. \& Draina, L. (2010). Leadership development of team captains in collegiate varsity athletics. Journal of College Student Development, 51(4), 403-418.

Hardy, S. (1987). Graduate curriculums in sport management: The need for a business orientation. Quest, 39(2), 207-216.

Hinck, H. S., \& Brandell, M. E. (2000). The relationship between institutional support and campus acceptance of academic service learning. The American Behavioral Scientist, 43(5), 868-882.

Hooijberg, R., \& Choi, J. (2001). The impact of organizational characteristics on leadership effectiveness models an examination of leadership in a private and a public sector organization. Administration \& Society, 33(4), 403-431.

Jackowski, M. M., \& Gullion, L. L. (1998). Teaching sport management through servicelearning: An undergraduate case study. Quest, 50(3), 251-265.

Jones, S., Gilbride-Brown, J., \& Gasiorski, A. (2005). Getting inside the "underside" of service-learning: Student resistance and possibilities. In Service-learning in higher education (pp. 3-24). Palgrave Macmillan US.

Kass, D. \& Grandzol, C. (2011). Learning to lead at 5,267 feet: An empirical study of outdoor management training and MBA students' leadership development. Journal of Leadership Education. 12(1), 41-62.

Kenworthy, A. L., \& Fornaciari, C. (2010). Guest editorial: No more reinventing the service-learning wheel: Presenting a diverse compilation of best practice "how to" articles. Journal of Management Education, 34(1), 3-8.

Kenworthy-U'Ren, A. L. (2008). A decade of service-learning: A review of the field ten years after JOBE's seminal special issue. Journal of Business Ethics, 81(4), 811.

Kolb, D.A. (1984): Experiential learning: experience as the source of learning and development. Englewood Cliffs, NJ: Prentice Hall.

Kouzes, J. M., \& Posner, B. Z. (2006). Student leadership practices inventory: Facilitator's guide (3rd ed.). San Francisco, CA: Jossey-Bass.

Kouzes, J. M., \& Posner, B. Z. (2007). The leadership challenge $\left(4^{\text {th }}\right.$ ed.). San Francisco, CA: Jossey-Bass. 
Kouzes, J.M., \& Posner, B.Z. (2008). The student leadership challenge: Five practice for exemplary leaders. San Francisco, CA: Jossey-Bass.

Kouzes, J., \& Posner, B. (2012). The leadership challenge: How to make extraordinary Things happen in organizations. Hoboken, NJ: Jossey-Bass.

Kuh, G. D. (2008). High-impact educational practices: What they are, who has access to them, and why they matter. Washington, DC: Association of American Colleges and Universities.

Litzky, B. E., Godshalk, V. M., \& Walton-Bongers, C. (2010). Social entrepreneurship and community leadership: A service-learning model for management education. Journal of Management Education, 34(1), 142-162.

Maak, T., \& Pless, N. M. (2009). Business leaders as citizens of the world. Advancing humanism on a global scale. Journal of Business Ethics, 88(3), 537-550.

McCarthy, J. P., \& Anderson, L. (2000). Active learning techniques versus traditional teaching styles: two experiments from history and political science. Innovative Higher Education, 24(4), 279-294.

Meek, A. (1997). An estimate of the size and supported economic activity of the sports industry in the United States. Sport Marketing Quarterly, 6(4), 15-21.

Mullin, B., Hardy, S., \& Sutton, W. (2007). Sport marketing ( $3^{r d}$ Ed.). Champaign, IL: Human Kinetics.

Ostrander, S. A. (2004). Democracy, civic participation, and the university: A comparative study of civic engagement on five campuses. Nonprofit and Voluntary Sector Quarterly, 33(1),74-93.

Parks, J. B., Quarterman, J., Thibault, L. (2007). Contemporary sport management. 3rd ed. Champaign, IL: Human Kinetics.

Pederson, P. M., Parks, J. B., Quarterman, J., \& Thibault, L. (2011). Contemporary Sport Management ( $4^{\text {th }}$ Edition). Champaign, IL: Human Kinetics.

Pless, N. M., Maak, T., \& Stahl, G. K. (2011). Developing responsible global leaders through international service-learning programs: The Ulysses. experience. Academy of Management Learning \& Education, 10(2), 237-260.

Plunkett Research Ltd. (2010). Sport industry overview. Houston, TX: Plunkett Research, Ltd.

Rhee K. S., \& Sigler, T. H. (2010). Developing enlightened leaders for industry and 
community: Executive education and service learning. Journal of Management Education, 34(1), 163-181.

Ricketts, J.C., \& Rudd, R. D. (2001). A comprehensive leadership education model to train, teach, and develop leadership in youth. Paper presented at the International Leadership Association.

Rozeboom, D. J. (2008). Self-report and direct observers' perceived leadership practices of chief student affairs officers in selected institutions of higher education in the United States (Doctoral dissertation). Available from ProQuest Dissertations and Theses database. (UMI No. 3333760)

Schumacher, L. G., \& Swan, M. K. (1993). Need for formal leadership training for students in a land-grant college of agriculture. Journal of Agricultural Education, 34(3), 1-9.

Snell, R.S., Chan, M.L., Ma, C.K. \& Chan, C. M. (2015). A road map for empowering undergraduates to practice service leadership through service-learning in teams. Journal of Management Education. 39(3), 372-399.

Soslau, E. G., \& Yost, D. S. (2007). Urban service-learning: An authentic teaching strategy to deliver a standards-driven curriculum. Journal of Experiential Education, 30(1), 36-53.

Soucie, D. (1994). Effective managerial leadership in sport organizations. Journal of Sport Management, 8, 1-13.

Spring, K, Dietz, N., \& Grimm, R. (2006). Youth helping America: Service-learning, school-based service and youth civic engagement. Washington, DC: Corporation for National \& Community Service.

Stanton, T. K., Giles, J., Dwight E., \& Cruz, N. I. (1999). Service-learning: A movement's pioneers reflect on its origins, practice, and future. San Francisco, CA: JosseyBass Publishers

Stier, W. F., Jr. (1993). Alternative career paths in physical education: Sport management. ERIC digest, 93(1), 1-2.

Taylor, T., Martin, B. N., Hutchinson, S., \& Jinks, M. (2007). Examination of leadership practices of principals identified as servant leaders. International Journal of Leadership in Education, 10(4), 401-419.

The sport industry needs good leaders. (2015, July 28). Retrieved from https://www.msm.nl/the-sport-industry-needs-good-leaders/ 
Titlebaum, P., Williamson, G., Daprano, C., Baer, J., \& Brahler, J. (2004). Annotated History of Service-Learning. Dayton, OH: University of Dayton.

Wilczenski, F. L. \& Coomey, S. M. (2007). A practical guide to service learning: Strategies for positive development in schools. New York, NY: Springer Publishing Company.

Wurr, A. J., \& Hamilton, C. H. (2012). Leadership development in service-learning: An exploratory investigation. Journal of Higher Education Outreach and Engagement, 16(2), 213-239.

\section{Author Biographies}

Bryan Romsa, EdD is an Assistant Professor of Sport Management in the Department of Health and Nutritional Sciences at South Dakota State University.

Katelyn Romsa, EdD is an Assistant Professor of Counseling and Human Development specializing in Student Affairs and Higher Education Administration at South Dakota State University.

Jon Lim, EdD is an Associate Professor of Sport Management in the Department of Human Performance at Minnesota State University, Mankato.

Scott Wurdinger, $\mathrm{PhD}$ is a Professor of Experiential Education and Leadership Studies at Minnesota State University, Mankato. He currently serves as the coordinator of the Educational Leadership Doctoral Program. 